Article

\title{
A New System to Estimate and Reduce Electrical Energy Consumption of Domestic Hot Water in Spain
}

\author{
Alberto Gutierrez-Escolar ${ }^{1, *}$, Ana Castillo-Martinez ${ }^{1}$, Jose M. Gomez-Pulido ${ }^{1}$, \\ Jose-Maria Gutierrez-Martinez ${ }^{1}$ and Zlatko Stapic ${ }^{2}$
}

1 Department of Computer Sciences, Polytechnic School, University of Alcala, Road Madrid-Barcelona, Km 33.6, Alcala de Henares 28871, Spain; E-Mails: ana.castillo@uah.es (A.C.-M.); jose.gomez@uah.es (J.M.G.-P.); josem.gutierrez@uah.es (J.-M.G.-M.)

2 Faculty of Organization and Informatics, University of Zagreb, Pavlinska 2, Varazdin 42000, Croatia; E-Mail: zlatko.stapic@foi.hr

* Author to whom correspondence should be addressed; E-Mail: alberto.gutierreze@uah.es; Tel.: +34-9188-56651; Fax: +34-9188-56646.

External Editor: Stephen Treado

Received: 16 May 2014; in revised form: 7 October 2014 / Accepted: 17 October 2014 /

Published: 24 October 2014

\begin{abstract}
Energy consumption rose about 28\% over the 2001 to 2011 period in the Spanish residential sector. In this environment, domestic hot water (DHW) represents the second highest energy demand. There are several methodologies to estimate DHW consumption, but each methodology uses different inputs and some of them are based on obsolete data. DHW energy consumption estimation is a key tool to plan modifications that could enhance this consumption and we decided to update the methodologies. We studied DHW consumption with data from 10 apartments in the same building during 18 months. As a result of the study, we updated one chosen methodology, adapting it to the current situation. One of the challenges to improve efficiency of DHW use is that most of people are not aware of how it is consumed in their homes. To help this information to reach consumers, we developed a website to allow users to estimate the final electrical energy needed for DHW. The site uses three estimation methodologies and chooses the best fit based on information given by the users. Finally, the application provides users with recommendations and tips to reduce their DHW consumption while still maintaining the desired comfort level.
\end{abstract}


Keywords: estimation; methodology; residential buildings; water consumption

\section{Introduction}

Nowadays, energy consumption is rising every year in every country. This permanent increase will not be sustainable in the long run, and energy saving has become an important environmental concern. Spain is not different in this trend as it can be seen in Table 1. Industry is the only case of decrease in final energy consumption, while the residential sector had one of the biggest rises, of about $28 \%$.

Table 1. Final energy consumption by sector in Spain (Mtoe) [1].

\begin{tabular}{ccccccccccc}
\hline Country & \multicolumn{2}{c}{ Total } & \multicolumn{2}{c}{ Industry } & \multicolumn{2}{c}{ Transport } & \multicolumn{2}{c}{ Residential } & \multicolumn{2}{c}{ Services } \\
\hline Period & 2001 & 2011 & 2001 & 2011 & 2001 & 2011 & 2001 & 2011 & 2001 & 2011 \\
Spain & 83.50 & 86.53 & 27.13 & 21.18 & 34.32 & 36.04 & 12.61 & 16.22 & 7.05 & 9.54 \\
\hline
\end{tabular}

In the case of Spanish residential buildings, energy consumption is divided as follows: space heating $46 \%$, domestic hot water $20 \%$, appliances $16 \%$, cooking $10 \%$ and lighting $7 \%$ [2]. Research results shown in this paper are focused on Domestic Hot Water (DHW), which is the second most important energy consumption, justifying efforts made to reduce it.

The average energy consumption of Spanish households is $10521 \mathrm{kWh}$ per year [3]; which means that energy consumption in DHW is $2104.2 \mathrm{kWh}$ per year. However, not every single home consumes the same amount of energy. If we compare consumption in houses with different weather conditions like houses in the North Atlantic Area, with lower temperatures, and houses in the Mediterranean Area, with higher, we can notice a huge difference in consumption. Data from the three main areas to consider can be seen in Table 2 .

Table 2. Annual average domestic hot water (DHW) energy consumption per house in different regions from Spain [3].

\begin{tabular}{ccc}
\hline Region & Number of Provinces & Annual Average Energy Consumption (kWh) \\
\hline North Atlantic Area & 6 & 2262.40 \\
Mediterranean Area & 18 & 1755.90 \\
Continental Area & 28 & 2286.50 \\
\hline
\end{tabular}

Recent research made by Rodriguez-Hidalgo [4] shows that DHW consumption depends not only on the geographical situation, but also on people's habits, the time of year, and the purpose of the building. Differences shown in Table 2 could be caused by inlet temperature of cold water or other parameters. We made a review of variables affecting the amount of energy used to heat water in order to find the reason for differences.

The first step is to try to understand factors influencing energy consumption and to observe existing models. However, although several DHW consumption models exist, they are often outdated and most fail to identify the influence of the number of occupants in the dwellings [5]. A good example of that is the model developed by Gilbert [6] for Electric Power Research (EPRI). This model was based on data 
collected before 1980 but buildings and their uses have evolved since this date. In addition, this model has another huge drawback in the sample chosen, which was based only on data from single-family houses. Another example is the ERÅD model (EnergiRÅDgivning) [7], which decomposes household electricity consumption into different end uses (hot water, lighting, electric appliances and space heating). In this case, data used to create the model was collected in 1990 and could be outdated.

The main goal of this work was to update data of existing methodologies through an analysis of DHW consumption. The secondary goal was to create a website to allow households to estimate their DHW energy consumption. This secondary goal was introduced taking into account that one of the challenges to improve the efficiency of DHW use is that most of people are not aware of how DHW is consumed and managed in their homes [8]. The site allows estimation using three different models depending on the available information, giving citizens an evaluation of their consumption and providing them with knowledge of how to reduce it.

The remainder of this paper is organized as follows. The following section contains the analysis of parameters used in methodologies, then methodologies are analyzed and updated in the next section. The website and its contributions are described in the fourth section and, finally, results and conclusions are shown.

\section{Analysis of Relevant Factors for Methodologies}

We started the analysis by making a systematic literature review to look for relevant factors and we made the findings shown in this section.

One of the most important factors that must be taken into account before starting to develop the study is the type of building. According to Ndoye [9], it is essential to know the type of building because it affects other factors thus influencing in different ways. Furthermore, this research shows that energy consumption may be considered dependent on the flow rate.

The research conducted by Bouchelle [10] showed that pipe insulation does not affect the energy consumption. Aydinalp [11] developed a neural network to estimate DHW energy consumption, assuring that the energy savings are insignificant in addition of insulation around hot water pipes.

In the research carried out by Yao [12] the equation used to estimate the DHW load (kWh per day) does not take into account the floor area, but it includes heat capacity of water, density of water, daily volume and difference of temperature between cold inlet water and DHW consumed.

After in-detail analysis of previous researches, the differences on the number and the kind of factors used are identified and shown in Table 3.

Factors used in each research are significantly different with a small common part. Considering these researches, the most relevant factors are: type of building, amount of DHW consumed (equivalent to Flow rate but easier to obtain), cold inlet temperature and temperature of DHW.

However, in order to determine the definitive set of factors, we study further these factors and its relations. We will study main factors which influence the electrical energy consumption for DHW. 
Table 3. Influential factors used in each research.

\begin{tabular}{ccccc}
\hline Influential Factors & Ndoye [9] & Bouchelle [10] & Aydinalp [11] & Yao [12] \\
\hline Type of building & Yes & Yes & Yes & Yes \\
Flow rate (L/in) & Yes & No & Yes & No \\
Regional climate & No & No & No & Yes \\
DHW temperature & Yes & Yes & Yes & Yes \\
Heat tank losses & Yes & Yes & Yes & No \\
Time of the year & No & Yes & No & Yes \\
Solar water heaters & No & Yes & No & No \\
Pipe insulation & No & No & No & No \\
Occupancy & No & Yes & No & Yes \\
Household income & No & No & Yes & No \\
Dwelling ownership & No & No & Yes & No \\
Area of residence & No & No & Yes & No \\
Energy sources used & No & No & Yes & No \\
Number of water heaters & No & No & Yes & No \\
Age of system & No & No & Yes & No \\
Size of the water tank & No & No & Yes & No \\
\hline
\end{tabular}

\subsection{Temperature Difference}

Temperature difference could be an important factor and in order to make a thorough study of it, an evaluation of two different magnitudes was required: cold inlet temperature and referenced temperature.

Unexpectedly, one of the software used to calculate the energy label of residential buildings in Spain $\left(\mathrm{CE}^{3} \mathrm{X}\right)$ [13] uses constant value for the water inlet temperature. Table 4 shows the average annual inlet temperatures in each climatic zone.

Table 4. Average annual inlet temperature of water regarding the climatic zone in Spain.

\begin{tabular}{ccc}
\hline Climatic Zone & Number of Provinces & Water Inlet Temperature $\left({ }^{\circ} \mathbf{C}\right)$ \\
\hline A3 & 5 & 15.50 \\
A4 & 1 & 16.00 \\
B3 & 6 & 14.58 \\
B4 & 4 & 15.50 \\
C1 & 6 & 12.75 \\
C2 & 3 & 13.75 \\
C3 & 1 & 13.25 \\
C4 & 4 & 13.75 \\
D1 & 4 & 10.90 \\
D2 & 8 & 11.83 \\
D3 & 6 & 13.00 \\
E1 & 4 & 10.08 \\
\hline
\end{tabular}

Data presented in Table 4 does not include the variation of temperature during the year, such information is represented in Figure 1 that shows the variation of cold water inlet temperature through different months of the year for the case of Seville (Spain) [14]. During the summer season, 
the ambient temperature is higher and the inlet temperature of cold water also increases. Other research [15] verified the results obtained for Seville with inlet temperature of cold water.

Figure 1. Cold inlet temperature along the year in Seville (Spain).

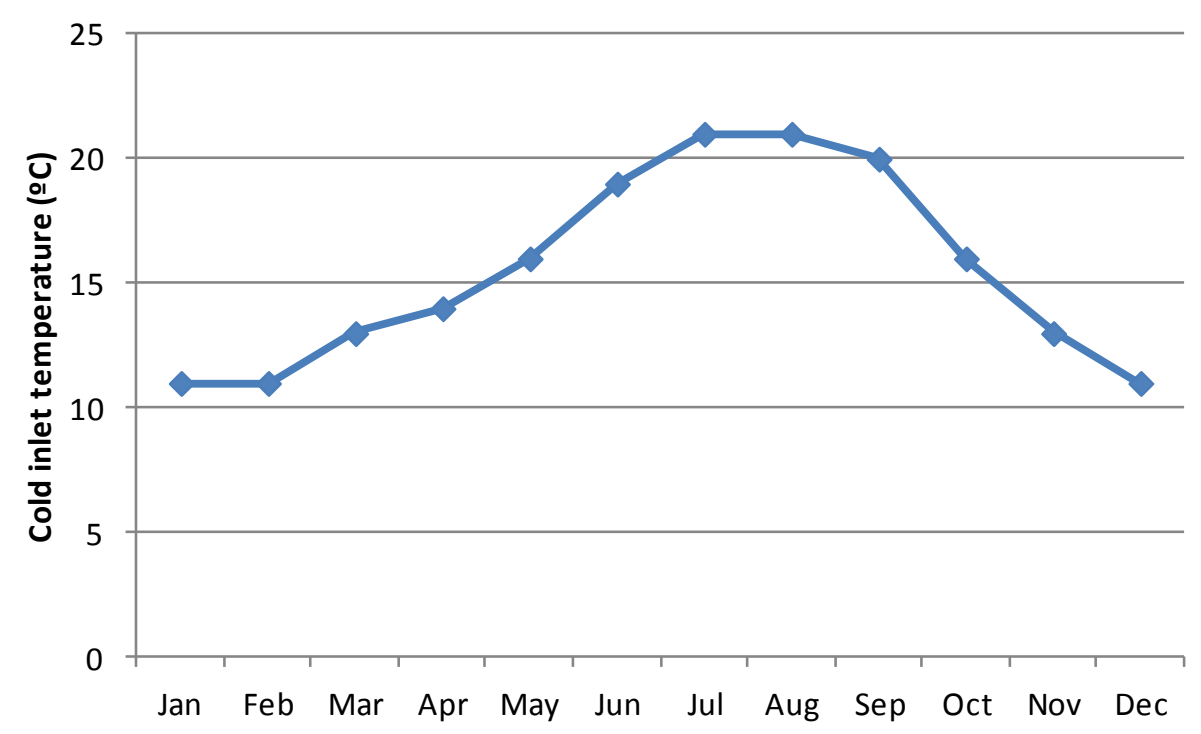

Another relevant factor is the reference temperature of DHW. This temperature influences the growth of Legionellae bacteria, which survives at temperatures below $20^{\circ} \mathrm{C}$ but is unlikely to multiply. When the temperature rises above $50{ }^{\circ} \mathrm{C}$, legionellae has little likelihood of survival, and at $60{ }^{\circ} \mathrm{C}$ the majority dies. Therefore, maintaining the temperature below $20{ }^{\circ} \mathrm{C}$ and above $50{ }^{\circ} \mathrm{C}$ is the main method of controlling legionellae in DHW [16]. However, if we analyze some European standards, we realize that the reference temperature is always $60{ }^{\circ} \mathrm{C}$. Standards establish the temperature of $60{ }^{\circ} \mathrm{C}$ to be sure that there is no risk of legionellae for tenants in residential buildings. However, there is another problem when water is stored at $60{ }^{\circ} \mathrm{C}$, the risk of DHW scalds for the elderly. Adults may show partial thickness burns in $30 \mathrm{~s}$ at a temperature of $55^{\circ} \mathrm{C}$, or in $5 \mathrm{~s}$ at $60{ }^{\circ} \mathrm{C}$, or in $1 \mathrm{~s}$ at $65^{\circ} \mathrm{C}$. This issue was studied in the research conducted by Stone [17] who showed noteworthy results from UK, because in some houses, temperatures reached up to $74.8{ }^{\circ} \mathrm{C}$.

Recommendations of the Technical Building Code (CTE, Codigo Técnico de la Edificación) [18] establish that the DHW consumption per capita should be 22 liters per day in apartment houses, and 30 liters per day in the case of detached houses. Portugal's standard [19] determines an average consumption of 40 liters per capita per day (LPCD). The standard from the UK known as BS6700 [20], recommends that DHW consumption of a dwellings should be between 35 liters and 45 liters per bedroom, respectively. To transfer the information into the Spanish scenario, UK bedrooms should be translated into tenants. According to CTE [18], which establishes the connection between tenants and bedrooms of houses, the quantity of DHW use per capita is similar to the Spanish standard. Table 5 shows an approximation between the consumption per user of those recommendations. It could be observed that standards share the same reference temperature; however, while Spain and the UK propose similar consumption values, Portuguese values are much higher. 
Table 5. Amount of DHW (LPCD) using different standards.

\begin{tabular}{ccccc}
\hline Standard & 1 Tenant & 2 Tenants & 3 Tenants & 4 Tenants \\
\hline Spanish CTE $\left(60^{\circ} \mathrm{C}\right)$ & $22-30$ & $44-60$ & $66-90$ & $88-120$ \\
United Kingdom Standard $\left(60^{\circ} \mathrm{C}\right)$ & $23-30$ & $47-60$ & $70-90$ & $105-135$ \\
Portuguese Standard $\left(60^{\circ} \mathrm{C}\right)$ & 40 & 80 & 120 & 160 \\
\hline
\end{tabular}

\subsection{Water Distribution}

In addition, it was considered interesting to study the water distribution in order to understand better where the DHW is consumed. The first step was to know the average water consumption. Thanks to the survey made by the National Statistical Office (INE) [21], information was obtained about water consumption in all autonomous Spanish communities. The Spanish average consumption in 2012 was 142 LPCD. The highest average water consumptions were in Castille and Leon, Ceuta and Melilla, while the lowest average water consumptions were in homes from Basque Country and La Rioja.

After analyzing the previous study, it was considered appropriate to check the previous values and to obtain more detailed data. To validate the data of total water consumption, it was decided to carry out a survey where the information was collected through a webpage [22]. To fill out the questionnaire, survey respondents were asked about the main characteristics of the house, such as the size, number of tenants, province, water billings, and so on. The houses evaluated are located in the Community of Madrid. Table 6 shows the average water consumption collected by the survey and the deviation with respect to the INE values that, in the case of the Community of Madrid, is 141 LPCD. As can be seen in Table 6, the average deviation produced by these data is only $-5.3 \%$, an acceptable deviation to validate the survey and extract the rest of data of the survey respondents.

Table 6. Comparison between survey and National Statistical Office (INE) data.

\begin{tabular}{ccc}
\hline Survey House & Water Consumption (LPCD) & Deviation with Respect to the INE Value \\
\hline House 1 & 115.0 & $-18.3 \%$ \\
House 2 & 169.3 & $+20.1 \%$ \\
House 3 & 170.8 & $+21.1 \%$ \\
House 4 & 132.3 & $-6.1 \%$ \\
House 5 & 188.8 & $+33.9 \%$ \\
House 6 & 98.6 & $-30.0 \%$ \\
House 7 & 105.2 & $-25.3 \%$ \\
House 8 & 87.6 & $-37.8 \%$ \\
Average & 133.4 & $-5.3 \%$ \\
\hline
\end{tabular}

The next step is to study the variation of consumption throughout the year. Figure 2 shows some examples of the variation of water consumption per tenant.

As can be seen in Figure 2, water consumption remains almost constant during the different months, except in summer, which is the holiday period. Furthermore, the most impacting issue is the large differences in total water consumption per tenant. This situation was detected also by Sauri [23] who studied the water consumption of 40 neighborhoods of Barcelona and reported on important differences within regions. Some municipalities consume more than 400 LPCD, while others consume 
only 110 LPCD. One work conducted by the Institute of Geography of the University of Alicante [24] ran a detailed study of some coastal neighborhoods and obtained results showing that housing holding up to four members reached values ranging from 140 to 180 LPCD.

Figure 2. Variation of water consumption per tenant throughout the year.

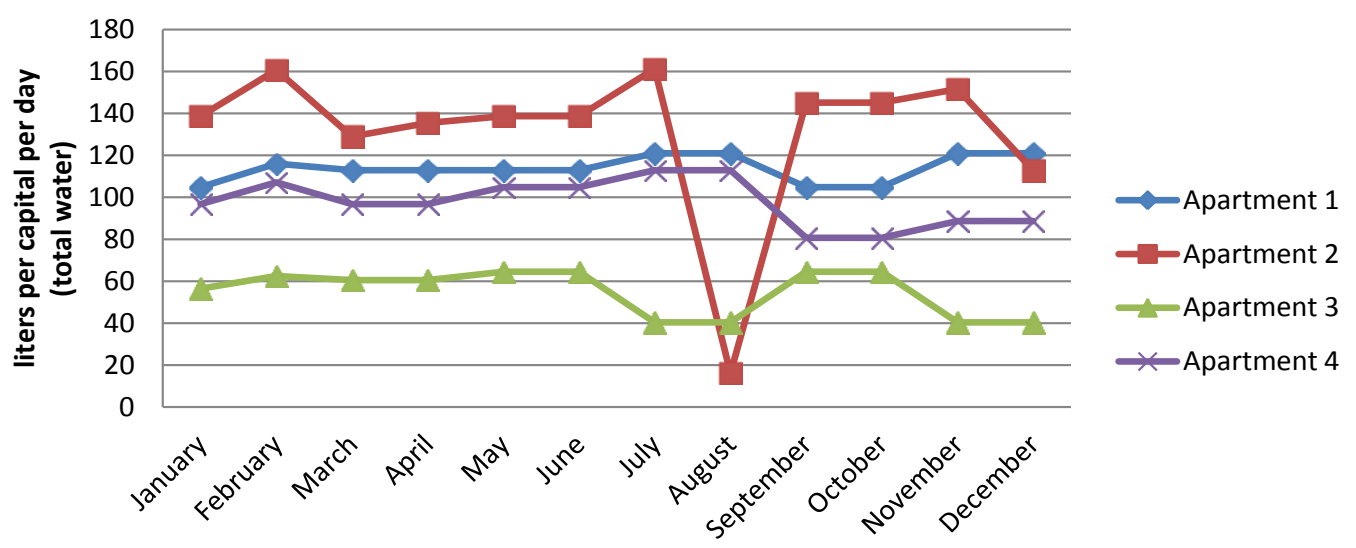

The next step in this study was to establish the water distribution. The research carried out by the Water Technology Institute of the Polytechnic University of Valencia [25] studied a sample composed of 64 building apartments without gardens, located in four different villages on the east coast of Spain where the measurements were performed during 807 days. The water distribution obtained in this study is the following: faucets $(38.6 \%)$, toilets $(22.2 \%)$, showers $(19.9 \%)$, clothes washers $(9.7 \%)$, leaks $(8.9 \%)$ and dishwashers $(0.6 \%)$. These percentages represent the consumption of cold water and DHW. Thus, if we take into account that most of the DHW is used in the showers and in the faucets, because toilets only consume cold water, the biggest savings of energy will be made by replacing them [26].

\subsection{Domestic Hot Water Bills}

To continue the study we decide to collect more detailed data and we select 10 apartments of the same building in Alcala de Henares (Spain) where we collect data during eighteen months. We focused on these households because they have solar thermal power equipment with an exclusive meter for DHW consumption. Therefore, we can draw the data about the amount of DHW through their DHW bills. Figure 3 shows the amount of DHW in one house during eighteen months.

By observing these data, we can conclude that DHW does not remain constant along the year, noticing that the same month in different years the consumption is completely different. For example, the consumption in March 2013 was 31.8 while in March 2014 was 21.5 LPCD. If we pay attention to the outdoor average temperature, we can appreciate that in March 2013 this temperature was $8.3{ }^{\circ} \mathrm{C}$ and in March 2014 was $10.1{ }^{\circ} \mathrm{C}$. Outdoor temperature may influence in the increment of DHW consumption. This issue was also studied by Parker [27], who demonstrated that DHW consumption is not totally dominated by weather conditions, but is sensitive to temperature conditions. This is why colder air temperatures lead to greater DHW consumption use because tenants take longer showers to warm up and use more amounts within the mix to achieve the preferred temperature. The tendency rises from summer to autumn and from autumn to winter. If we analyze the data in detail, we can see 
that the amount of DHW consumed in winter may be even four times higher than during summer. The average amount of DHW consumption was 25.7 LPCD. The month with the highest consumption was January with 43.1 LPCD, and the month with the lowest consumption was July with 9.7 LPCD. If we check this information with a Mediterranean country (Greece) where the weather conditions are very similar to Spain, we can see that both researches show similar results. This research was carried out by Papakostas [28] who showed that the majority of the families consume between 25 and 35 LPCD, and the season with lowest consumption was summer.

Figure 3. DHW consumption (LPCD) in one apartment.

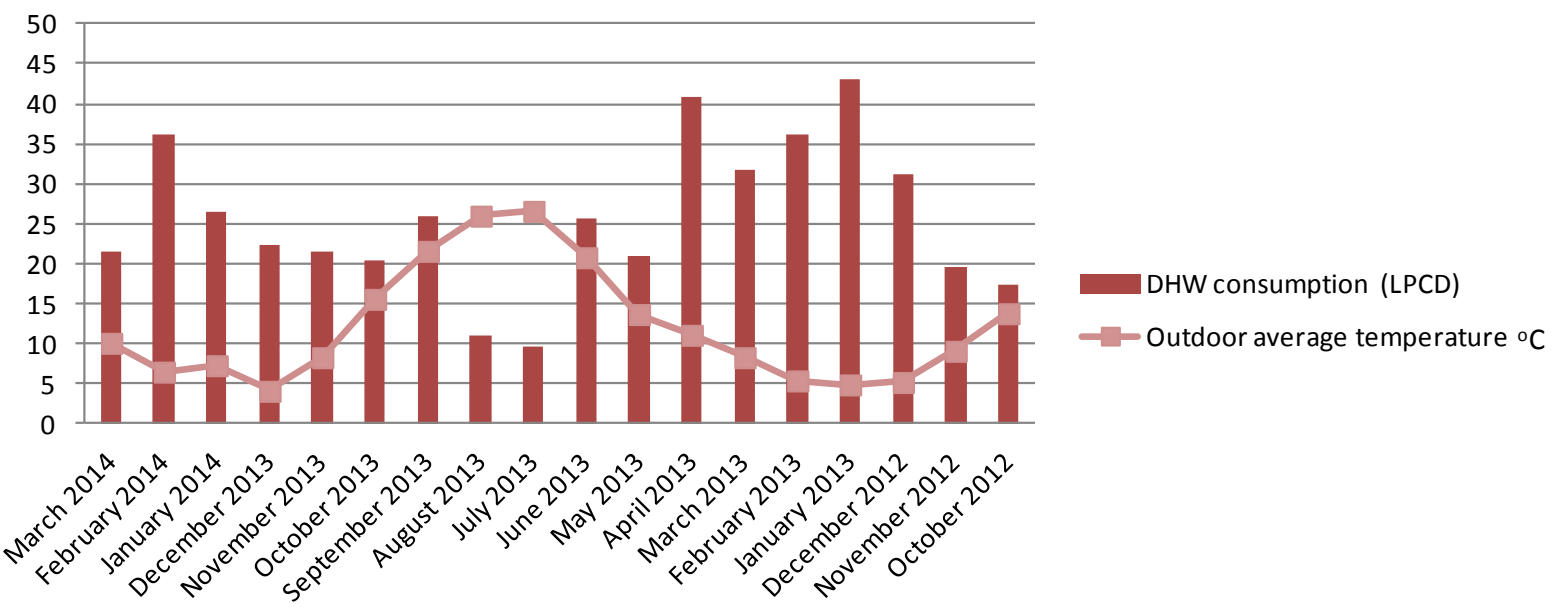

We can also pull out the data about energy consumption in order to check the benefit of this sort of installation. Figure 4 shows the energy consumption $(\mathrm{kWh})$ per month in the same apartment showed previously.

Figure 4. Energy consumption (kWh) in the same apartment.

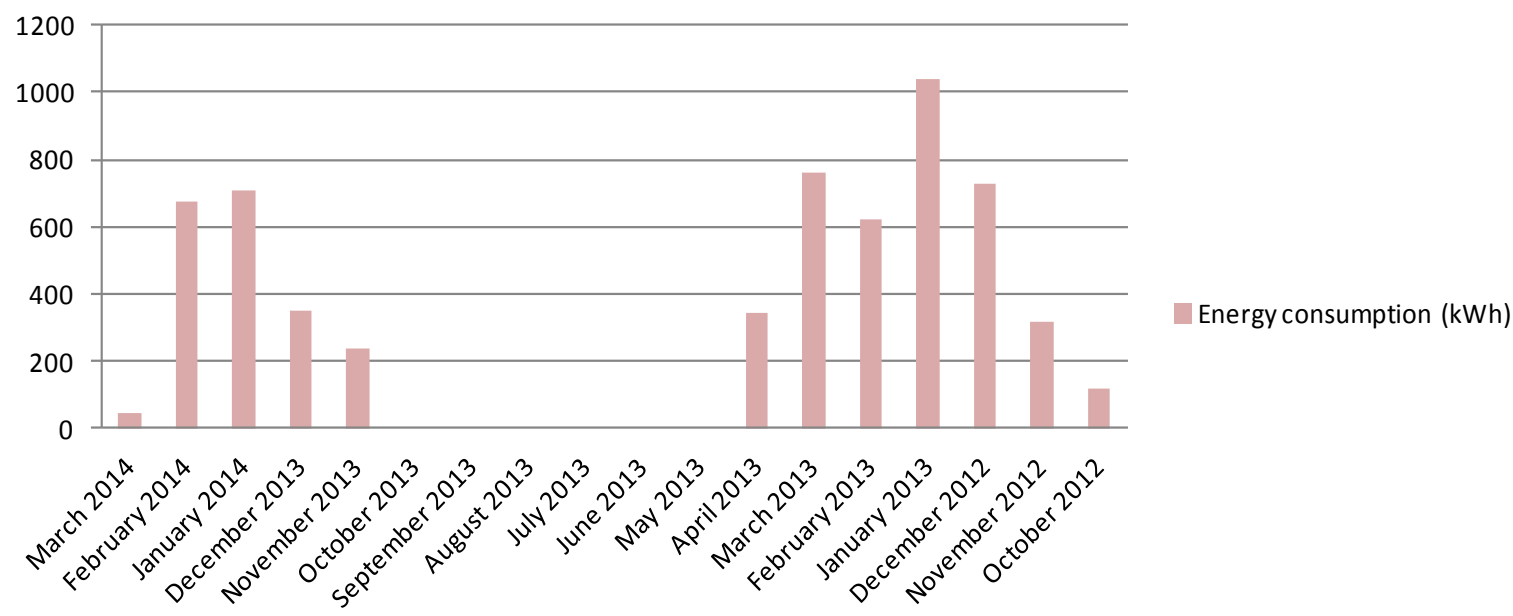

By observing these data, if the residential buildings have this sort of renewable energy, tenants could save on energy in their DHW bills up to six months per year. Hence the installation of solar thermal allows tenants to dramatically decrease the electrical energy bill.

Connecting the data of both figures (Figures 3 and 4), we can see that there are several months with 21 LPCP (March 2014, November 2013 and May 2013) while the electrical energy consumption is 
completely different; $47 \mathrm{kWh}$ in March 2014, $237 \mathrm{kWh}$ November 2013 and $0 \mathrm{kWh}$ in May 2013. This is why the energy generated by solar thermal power equipment depends on weather conditions. If we analyze the normalizing of electrical energy consumption per DHW consumption, Table 7 shows the result.

Table 7. Normalizing electrical energy consumption per DHW consumption.

\begin{tabular}{cccc}
\hline Month & $\begin{array}{c}\text { DHW Consumption } \\
\text { (LPCD) }\end{array}$ & $\begin{array}{c}\text { Electrical Energy } \\
\text { Consumption (kWh) }\end{array}$ & $\begin{array}{c}\text { Normalizing } \\
\text { (kWh/LPCD) }\end{array}$ \\
\hline March 2014 & 21 & 47 & 2.23 \\
February 2014 & 36 & 678 & 18.83 \\
January 2014 & 26 & 711 & 27.34 \\
December 2013 & 22 & 349 & 15.86 \\
November 2013 & 21 & 237 & 11.28 \\
October 2013 & 20 & 0 & 0 \\
September 2013 & 26 & 0 & 0 \\
August 2013 & 11 & 0 & 0 \\
July 2013 & 10 & 0 & 0 \\
June 2013 & 25 & 0 & 0 \\
May 2013 & 21 & 0 & 0 \\
April 2013 & 40 & 346 & 8.65 \\
March 2013 & 31 & 762 & 24.58 \\
February 2013 & 36 & 623 & 17.30 \\
January 2013 & 43 & 1039 & 24.16 \\
December 2012 & 31 & 729 & 23.51 \\
November 2012 & 19 & 314 & 16.52 \\
October 2012 & 17 & 117 & 6.88 \\
\hline
\end{tabular}

We can observe that our sample is not lineal. The results in March 2014, November 2013 and May 2013 are completely different. On the other hand, the research done by UK Government [29] showed a lineal normalizing. This is why the sample was done with 112 houses without solar thermal power equipment. The electrical energy consumption in both cases depends on DHW consumption but if the residential buildings have solar thermal power, this normalizing is not lineal.

\section{Methodologies}

There are a few methodologies commonly used for the estimation of the DHW demand [30]. The system developed allows users to obtain the estimation of electrical energy by applying three methodologies.

For the first methodology it was considered appropriated to use the estimation of the electrical energy consumption following the procedure collected in the document made by the Spanish Institute for Diversification and Energy Saving (IDAE, Instituto para la Diversificación y Ahorro de la Energía) [31] which tries to obtain the energy demand based on the number of tenants. This method establishes $573 \mathrm{kWh}$ per capita for detached houses and $420 \mathrm{kWh}$ per capita for apartments. To obtain the previous data, it was estimated the water consumption per user following the standard UNE 
(Una Norma Española) 94002:2005 [14]. Other variables considered were cold inlet temperature $\left(15^{\circ} \mathrm{C}\right)$ and delivered temperature $\left(60^{\circ} \mathrm{C}\right)$.

For the second methodology, the system needs the specification of the kind of residential building (apartment or detached), the province and the household area. The data used in this option is based on two studies [32,33] made by the University of Seville. This option takes into account more specific parameters than the previous one. However, it is not able to estimate the consumption per month only annual consumption is offered. Table 8 shows the coefficients to estimate it in some provinces.

Table 8. Coefficients to estimate electrical energy consumption $\left(\mathrm{kWh} / \mathrm{m}^{2}\right.$ per year).

\begin{tabular}{ccc}
\hline \multirow{2}{*}{ Province } & \multicolumn{2}{c}{ Residential Building } \\
\cline { 2 - 3 } & Apartment & Detached \\
\hline Albacete & 13.1 & 17.9 \\
Alicante & 12.3 & 16.8 \\
Almeria & 12.1 & 16.6 \\
Avila & 13.7 & 18.7 \\
\hline
\end{tabular}

In the last methodology, more parameters are needed as, for example, the cold inlet temperature. It was taken into account the equation included in the normative UNE 94002:2005 [14]. This option allows obtaining the electrical energy consumption per month using the following Formula:

$$
D_{\text {DHW }}(\mathrm{kWh}) \text { per month }=D_{\text {month }} \times Q_{\text {DHW }} \times \rho \times C_{\mathrm{p}} \times\left(T_{\text {ref }}-T_{\mathrm{cw}}\right)
$$

where:

$D$ month: number of days in the month;

$\rho$ : density of water $(\mathrm{kg} / \mathrm{L})$;

$C_{\mathrm{p}}$ : specific heat of water $\left(\mathrm{kWh} / \mathrm{kg}{ }^{\circ} \mathrm{C}\right)$;

$T_{\text {ref: }}$ reference temperature $\left({ }^{\circ} \mathrm{C}\right)$;

$T_{\mathrm{cw}}$ : cold inlet temperature $\left({ }^{\circ} \mathrm{C}\right)$;

$Q_{\text {DHW: }}$ DHW at reference temperature (LPCD).

Once equations are defined, values used in the system must be defined. If users do not know some parameters, the application has to assume them like amount of DHW. Table 9 shows the amount of DHW per person per day considered.

Table 9. Amount of DHW considered in the third option.

\begin{tabular}{ccc}
\hline \multirow{2}{*}{ Season } & \multicolumn{2}{c}{ Domestic Hot Water (LPCD) } \\
\cline { 2 - 3 } & Apartment Houses & Detached Houses \\
\hline Autumn & 21 & 30 \\
Winter & 22 & 32 \\
Spring & 23 & 33 \\
Summer & 19 & 29 \\
\hline
\end{tabular}

The best way to check the correctness of these methodologies of calculation is by confronting it with the information of SECH-SPAHOUSEC project [3] which is the result of a survey on one 
hundred properties, thirty three per each climate zone. In this project, Spain was divided into three areas: North Atlantic, Continental and Mediterranean.

The main benefit of our methodologies is that they are able to estimate this consumption in each province, while the previous projects gave only the average consumption in each climatic zone. To be coherent with the confrontation, the assumptions considered in the different methodologies are: the number of tenants is three [34] and the average area of residential buildings in the case in North Atlantic is $93.7 \mathrm{~m}^{2}$, in Continental zone is $103.5 \mathrm{~m}^{2}$ and in Mediterranean zone is $103.8 \mathrm{~m}^{2}$ [3]. Figures 5-7 show the output of the three options for each province comparing them with the average of each these climate zones in SECH-SPAHOUSEC study.

Figure 5. Average energy consumption in kWh per house in a year (North Atlantic).

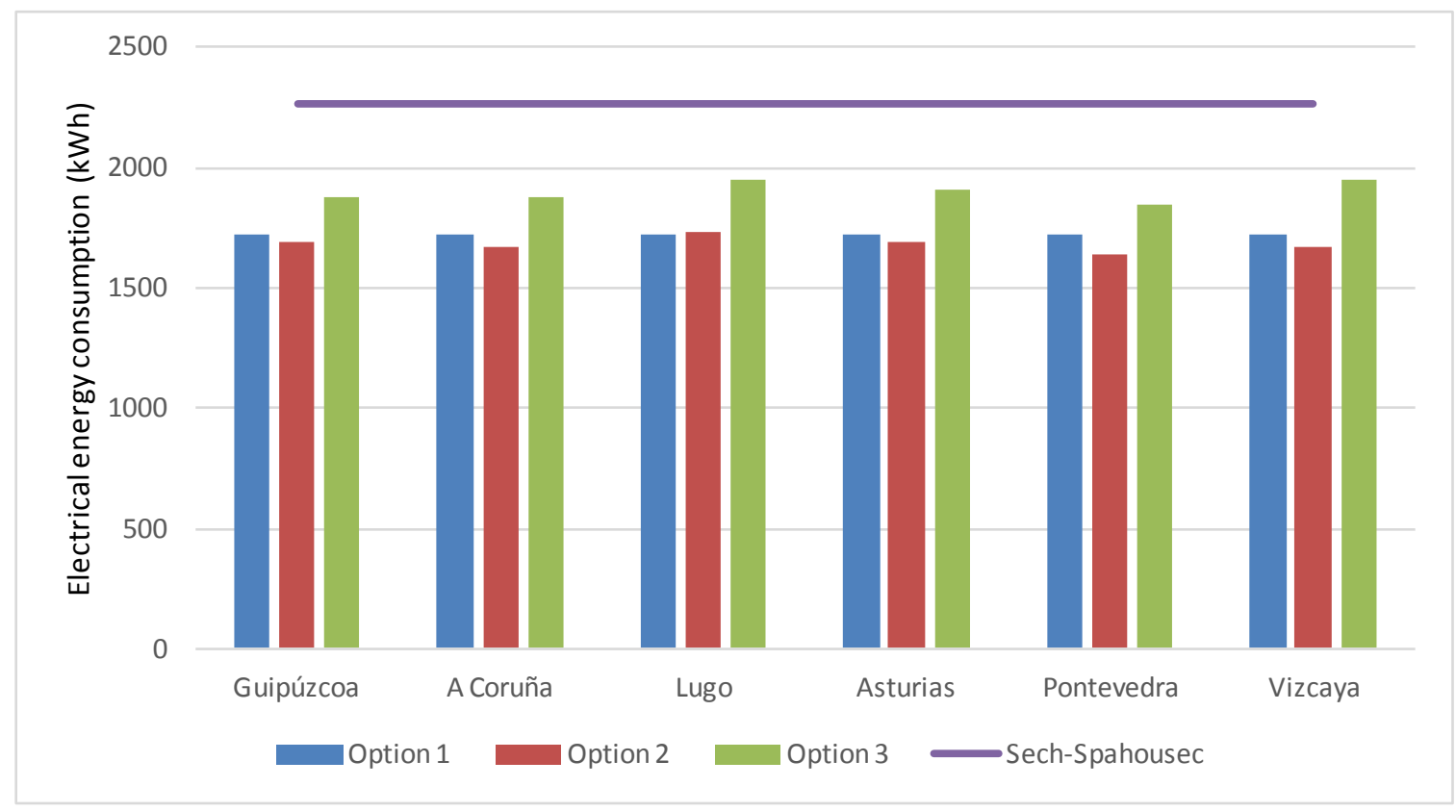

Figure 6. Average energy consumption kWh per house in a year (Continental).

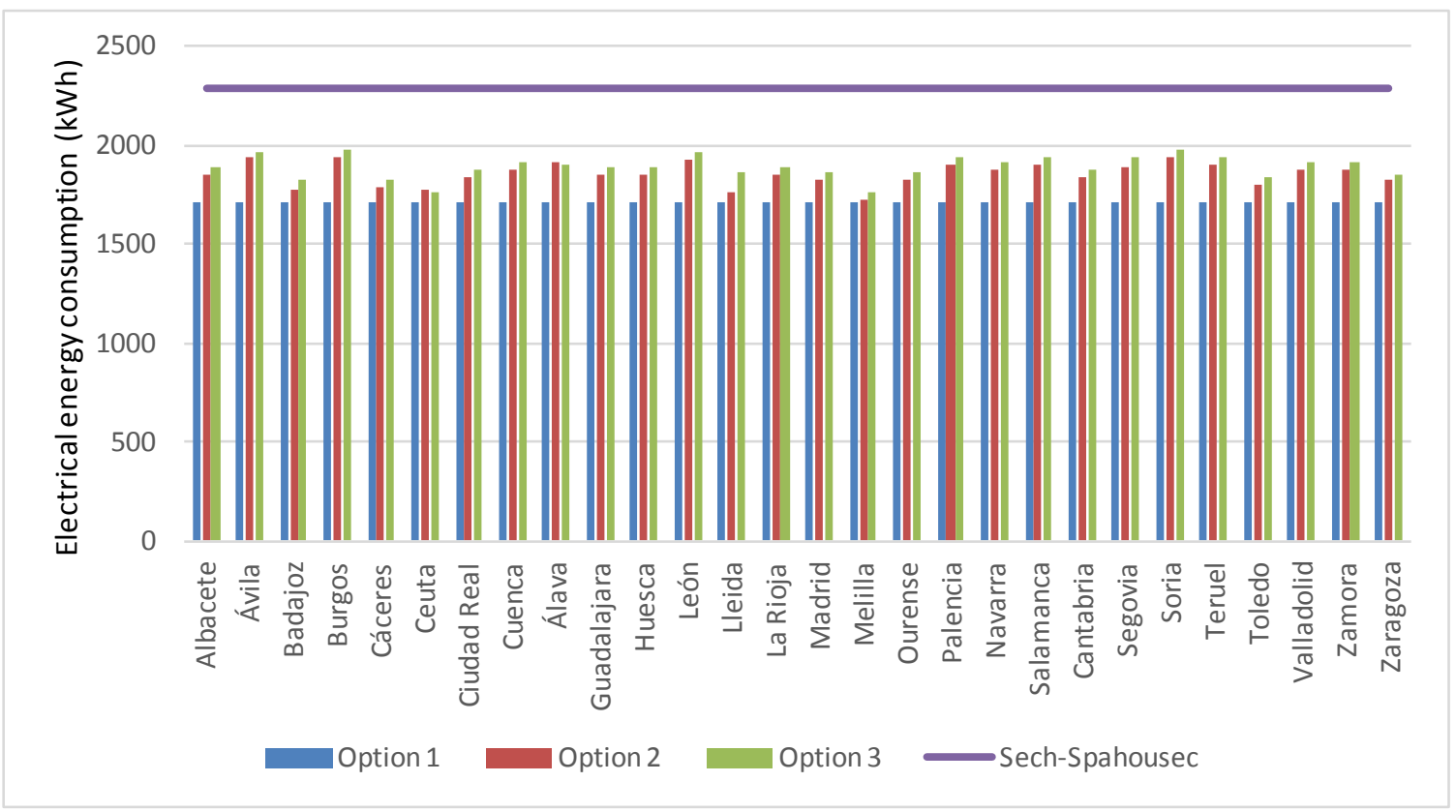


Figure 7. Average energy consumption per house in a year (Mediterranean).

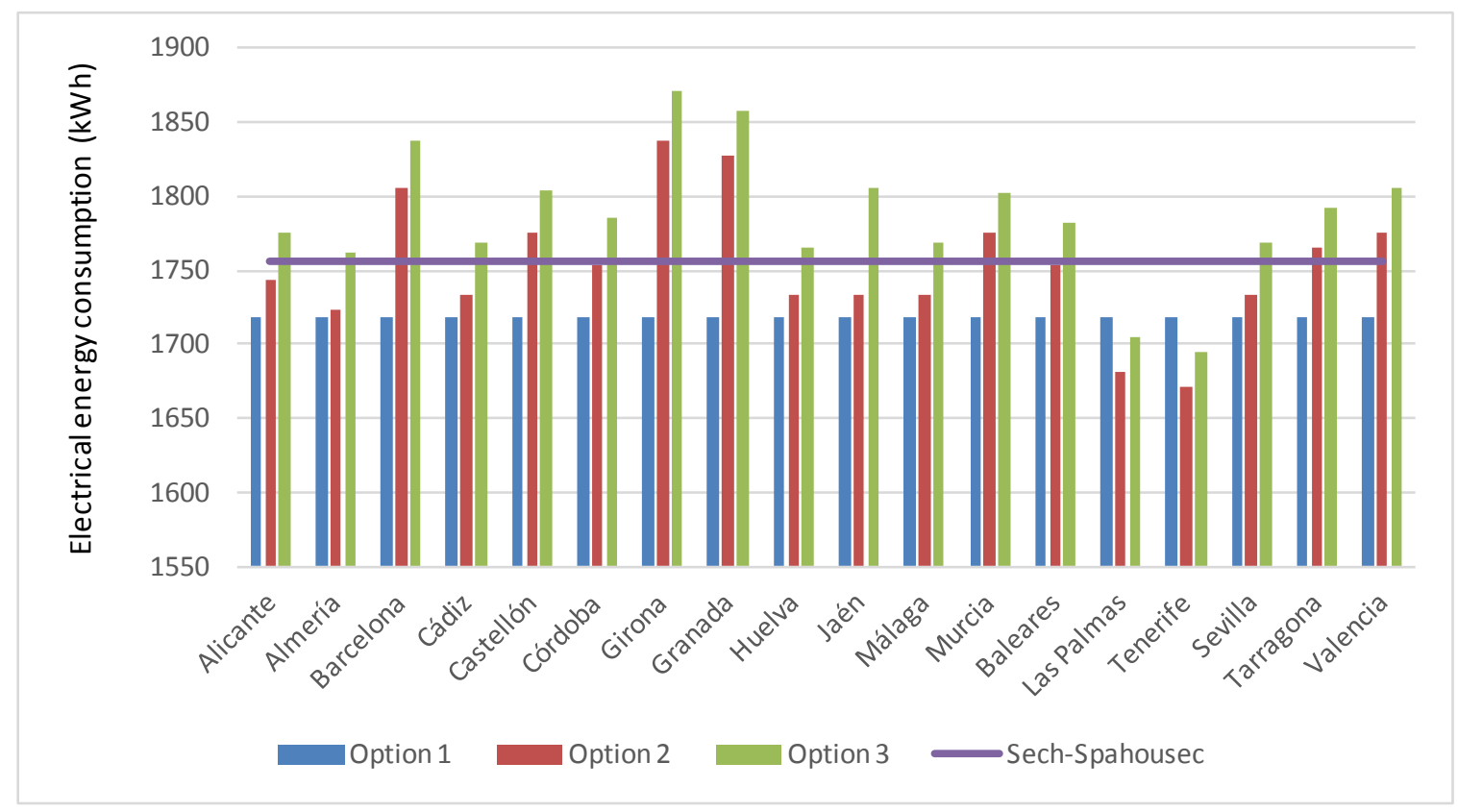

Analyzing the data of these Figures, we can notice that Santa Cruz de Tenerife and Las Palmas de Gran Canarias are the provinces with the lowest consumption while Burgos and Soria are the provinces with the highest consumption. Therefore, geographical situation influence is an important factor because it bears upon the cold inlet temperature.

If the results of the confrontation are analyzed deeply it is possible to observe differences on the accuracy of the predicted electrical energy consumption. Table 10 shows the deviation of each methodology divided by climatic zone.

Table 10. Deviation between the different options and Sech-Spahousec.

\begin{tabular}{cccc}
\hline Climatic Zone & Option 1 & Option 2 & Option3 \\
\hline North Atlantic & $-25 \%$ & $-26 \%$ & $-16 \%$ \\
Continental & $-25 \%$ & $-19 \%$ & $-18 \%$ \\
Mediterranean & $-3 \%$ & $-1 \%$ & $+2 \%$ \\
Average & $-18 \%$ & $-14 \%$ & $-11 \%$ \\
\hline
\end{tabular}

As it can be seen, the first option is the most inaccurate among the three options. The main problem with this option is that it keeps constant the cold inlet temperature and therefore it does not take into account the differences on temperature caused by weather conditions nor the season of the year. As a result, the output is the same for all Spanish cities. The second option estimates the consumption better, because the number of factors considered is higher than the first option. The most accurate methodology is the third option. Therefore, the higher the number of factors considered in the methodology, the less deviation in the output. 


\section{Estimation Web Tool for Householders}

To make these methodologies accessible to citizens, a website has been developed in order to allow users to easily estimate the electrical energy consumption with an intuitive interface. The aim of this new tool is to improve the awareness about the amount of energy used in DHW at home.

Due to the difficulty of some of the parameters of the methodologies used, the system provides three different levels of evaluation: basic, normal and complete. The main difference among them is the amount of information required to make the estimation, and the accuracy of the results. In the basic mode, only the kind of building and the number of tenants are required, while in the complete mode more information is required like the province, number of tenants, kind of building and the amount of DHW. As a result, the program gives the amount of electrical energy consumption of DHW. Each evaluation level will use a different methodology to make calculations.

Once known the consumption, the application offers small tips which can help to reduce it. To ease the visualization of these recommendations, they are differenced by rooms. Users can check the information about how save DHW in the bathroom or kitchen just placing the pointer on the appliance or device. Figure 8 shows the interface where it displays a range of different tips.

Figure 8. Piece of advice to reduce the energy consumption in DHW.

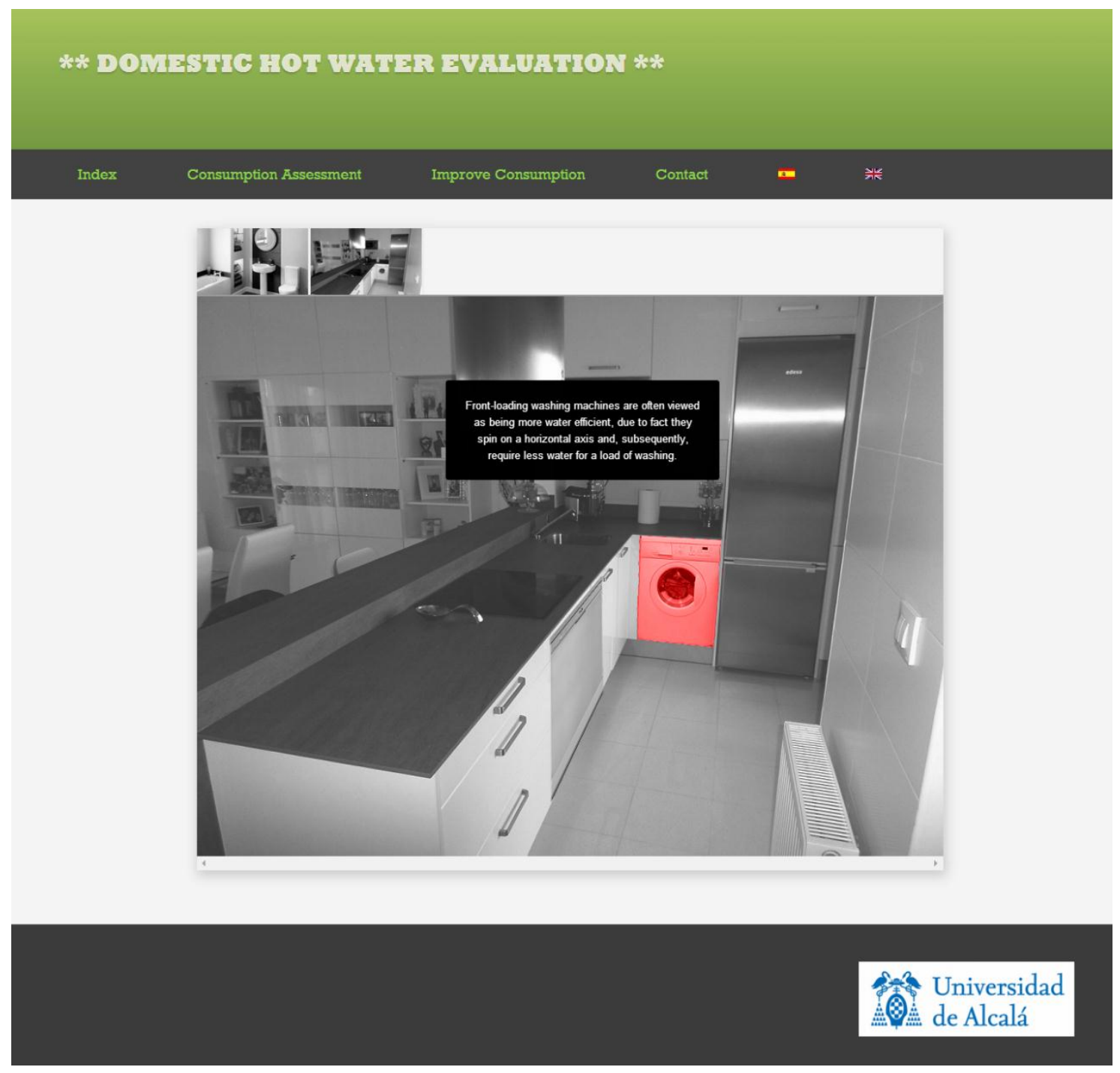


To help understanding of the website application and the selection of parameters and methodologies, a flow chart is provided in Figure 9, showing the behavior of the system.

Figure 9. Flow chart.

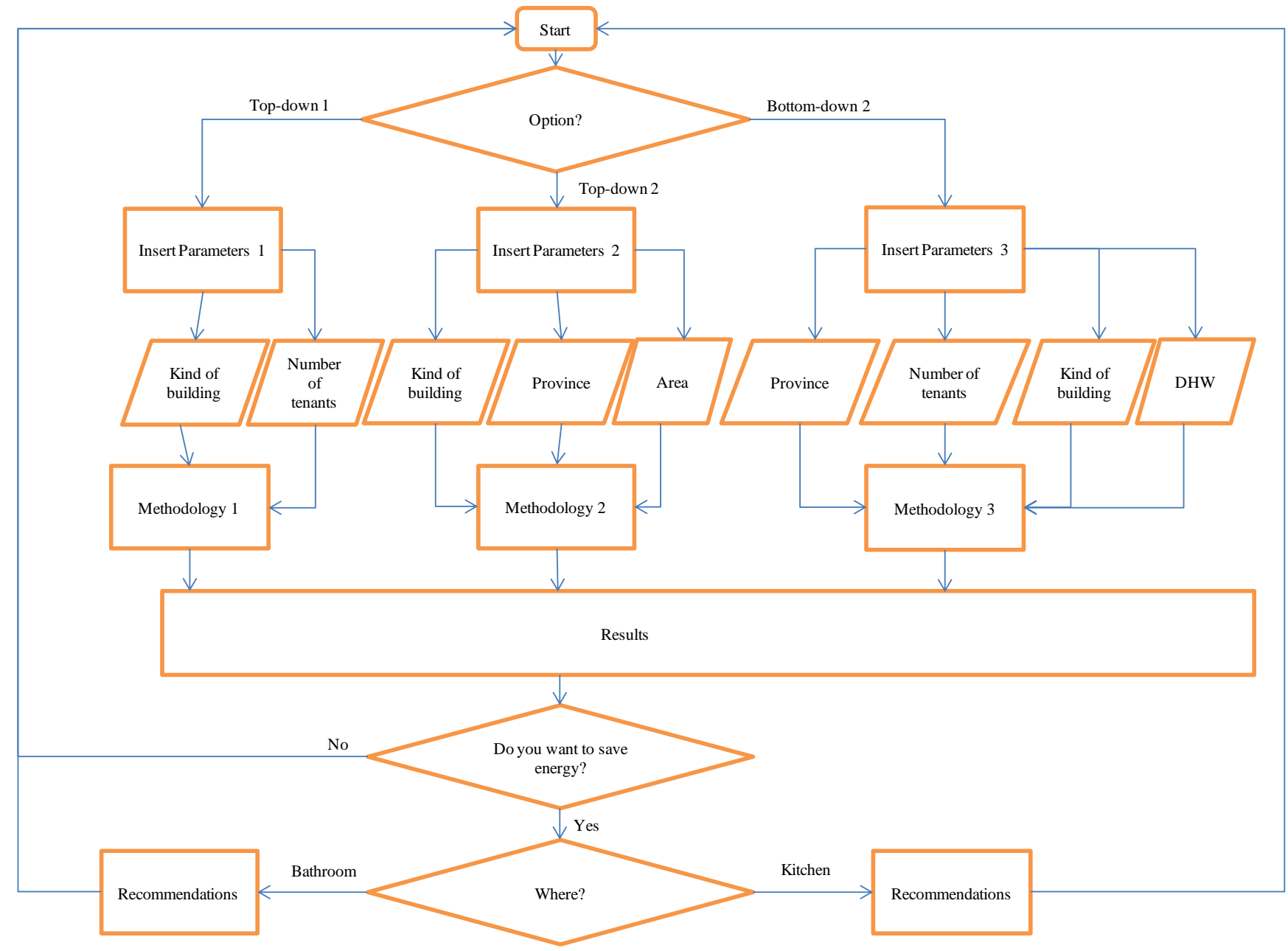

The last section of the flow chart shows the specialized recommendations for the kitchen and bathroom proposed by the program. The process to obtain this recommendations is showed in the following subsection.

\subsection{Selection of Recommendations}

The purpose of this section is to give users some technical advice to understand that devices and habits are able to reduce their DHW and energy consumption. According to Lutz [8] several technologies are available to enhance the system; saving energy and DHW consumption by reducing losses or by passively recovering heat from wastewater streams and other sources. Energy savings from some individual technologies are reported to be as much as 30 percent. Table 11 shows the percentage of residential buildings which have adopted some steps to reduce DHW consumption in Spain. 
Table 11. Percentage of residential buildings which have adopted steps to reduce DHW consumption (2008) [35].

\begin{tabular}{cc}
\hline Step Taken & Percent Incorporation \\
\hline Reusing water & $22.90 \%$ \\
Wait to fill up the dishwasher/washing machine & $81.90 \%$ \\
Decrease the flow of the faucets & $30.80 \%$ \\
\hline
\end{tabular}

It is noteworthy that no step is made with $100 \%$ incorporation. In addition, the incorporation percentage is not equally distributed in autonomous communities [36]. The percentage of reusing water is lower in communities with a high rate of rainwater. The Spanish Government should incorporate a full awareness program on water sensitive urban design.

There are two options to reduce the electrical energy consumption [37]: The first option is to use DHW more efficiently, so you need less of it without sacrificing comfort, and the second option needs that tenants invest money. Table 12 shows the recommendations of the first option.

Table 12. Recommendations to save energy and water.

\begin{tabular}{ll}
\hline Shower & $\begin{array}{l}\text { It is always better to shower than bathe. } \\
\text { Save energy by turning off the shower while you apply soap or shampoo. }\end{array}$ \\
\hline \multirow{3}{*}{ Dishwasher } & $\begin{array}{l}\text { Fill up the dishwasher before using, and use a middle-sized load only when it is an emergency. } \\
\text { If the dishes are washed by hand, do not do it with the water running. Use a stack to wash and } \\
\text { another to rinse. If you have two sinks, use a bowl [38]. }\end{array}$ \\
\hline & $\begin{array}{l}\text { Front-loading washing machines are often viewed as being more water efficient, due to the fact } \\
\text { they spin on a horizontal axis and, subsequently, require less water for a load of washing. These } \\
\text { machines, however, generally take twice the amount of time for a single washing cycle than a } \\
\text { top loader. New and more efficient top loaders on the market employ a variety of sensors and } \\
\text { cycles that minimize water usage for the amount of washing loaded into the machine [39]. }\end{array}$ \\
Mashing & $\begin{array}{l}\text { Use the washing machine at full load whenever possible [40]. } \\
\text { Most of the cost of operating washing machines is for heating the water. However, some } \\
\text { detergents are now specifically formulated to dissolve in cold water [37]. }\end{array}$ \\
\hline Faucet & Turn the hot water down or off while you shave or wash dishes. [37] \\
\hline
\end{tabular}

These apparently insignificant tips can have significant results when practiced routinely. According to the research did by Laitala [41] who measured energy and water consumption of different washing machines. Her results showed that washing at $30{ }^{\circ} \mathrm{C}$ used $0.37 \mathrm{kWh}$, at $40{ }^{\circ} \mathrm{C}$ used $0.526 \mathrm{kWh}$ and at $60{ }^{\circ} \mathrm{C}$ used $0.895 \mathrm{kWh}$. This means that washing at $30{ }^{\circ} \mathrm{C}$ used $29.6 \%$ less than washing at $40{ }^{\circ} \mathrm{C}$ and $58.7 \%$ less than washing at $60{ }^{\circ} \mathrm{C}$. If we assume that the number of cycles is 165 per year in Spain [42] and we consider temperatures of Table 13, the final energy consumption would be $74.96 \mathrm{kWh}$ per year.

Table 13. Water temperature in Washing Machines in 2008 (Spain) [35].

\begin{tabular}{ccccc}
\hline Number of Tenants & $\mathbf{1}$ & $\mathbf{2}$ & $\mathbf{3}$ & 4 or More \\
\hline Temperature $>40{ }^{\circ} \mathrm{C}$ & $1.7 \%$ & $2.1 \%$ & $1.6 \%$ & $2.2 \%$ \\
$30{ }^{\circ} \mathrm{C}<T<40{ }^{\circ} \mathrm{C}$ & $21.1 \%$ & $22.8 \%$ & $22.2 \%$ & $23.9 \%$ \\
Temperature $<30{ }^{\circ} \mathrm{C}$ & $60.8 \%$ & $57.7 \%$ & $56.2 \%$ & $52.7 \%$ \\
Depends on dirty & $16.4 \%$ & $17.5 \%$ & $20.0 \%$ & $21.2 \%$ \\
\hline
\end{tabular}


In the second option, users need to spend money to obtain energy savings, drawing on the research by Washlstrom [43]. In this research 65 flats in Gothenburg (Sweden) were measured where electrical energy consumption of DHW [44] is very similar to many Spanish cities. Results shows that $26 \%$ cold water and $28 \%$ DHW could be saved when modern taps were installed, thermostatic mixers in the bath/shower and single-lever mixer in the basin and kitchen. Single-lever mixers may save $51 \%$ cold water and 38\% DHW. Changing to thermostatic mixers and a single-lever mixer with eco-effect, with all installation costs included, will give a payback time of 2.4 years. To change to a single-lever mixer gives a payback time of 1.3 years if it is used by two persons and without any installation costs. Corresponding payback time for the single-lever basin mixer or a thermostatic mixer in the bath/shower is less than 1.9 years. Jensen [26] studied the amount of energy saving where it is possible to achieve it by changing to an energy-labelled tap or shower. In the case of an apartment, energy savings for DHW is in the range of 216 to $616 \mathrm{kWh}$ / (person, year) and for the case of detached the range is 147 to $420 \mathrm{kWh}$ /(person, year), these amounts of energy depend on the energy-labelled of the new device.

Considering all these results, the application was created to offer simplified recommendations to users including most of these results.

\section{Conclusions}

The main result of the presented work is the confirmation of feasibility for methodologies used to predict the amount of electrical energy used in DHW. Through the analysis of factors, and the evaluation of methodologies, it was possible to update one methodology with new considerations as the tendency.

In addition, some conclusions about factors arose in the study that offer results more detailed than previous studies. One of the most relevant indicates that in residential buildings with renewable energy, the electrical energy does not depend linearly of DHW consumption.

In addition, after analyzing the different options obtained to estimate the electrical energy consumption, the methodology used by current normative UNE 94002:2005 [14] should resolve two important aspects: first, it does not take into account the effects of the tendency because the amount of DHW consumption is considered constant along the year and second, it should incorporate the electrical energy saving of thermal solar power.

In addition, we would like to remark that autonomies with a high rate of rain do not take advantages of reusing water. From our point of view, it would be a good idea and an improvement if the Spanish Government incorporates a full awareness program on water sensitive urban design.

Finally, the application development within the website shows the feasibility of offering these complex methodologies with an easy to use interface making their result more widely spread.

\section{Acknowledgments}

Authors want to thank the effort and support from FERROVIAL Company to the Department of Computer Sciences in the Ciudad2020 project. Moreover, we are grateful to the tenants of the apartment buildings and the participants of the survey, without their support this research would not have been possible. Finally, we are immensely grateful to the anonymous reviewers for their valuable comments on the earlier versions of this manuscript. 


\section{Author Contributions}

Alberto Gutierrez-Escolar and Zlatko Stapic have contributed developing ideas and combining the methodologies into a website. Ana Castillo Martinez and Jose-Maria Gutierrez-Martinez have developed both websites. Jose M. Gomez-Pulido has obtained the data. All the authors are involved in preparing the manuscript.

\section{Conflicts of Interest}

The authors declare no conflict of interest.

\section{References}

1. Energy, Transport and Environment Indicators. Available online: http://epp.eurostat.ec.europa.eu/ cache/ITY_OFFPUB/KS-DK-13-001/EN/KS-DK-13-001-EN.PDF (accessed on 11 September 2014).

2. Banco Público de Indicadores Ambientales (BPIA). Available online: http://www.magrama.gob.es/es/ calidad-y-evaluacion-ambiental/temas/informacion-ambiental-indicadores-ambientales/banco-publicode-indicadores-ambientales-bpia-/ (accessed on 11 September 2014). (In Spanish)

3. Instituto para la Diversificación y Ahorro de la Energía (IDAE). Proyecto SECH-SPAHOUSEC Análisis del consumo energético del sector residencial en España. Available online: http://www. idae.es/index.php/mod.documentos/mem.descarga?file=/documentos_Informe_SPAHOUSEC_ACC_ f68291a3.pdf (accessed on 11 September 2014). (In Spanish)

4. Rodríguez-Hidalgo, M.C.; Rodríguez-Aumente, P.A.; Lecuona, A.; Legrand, M.; Ventas, R. Domestic hot water consumption vs. solar thermal energy storage: The optimum size of the storage tank. Appl. Energy 2012, 97, 897-906.

5. Evarts, J.C.; Swan, L.G. Domestic hot water consumption estimates for solar thermal system sizing. Energy Build. 2013, 58, 58-65.

6. Ladd, G.O.; Harrison, J.L. Electric Water Heating for Single-Family Residences: Group Load Research and Analysis; EPRI EA-4006; Electric Power Research Institute (EPRI): Palo Alto, CA, USA, 1985.

7. Larsen, B.M.; Nesbakken, R. Household electricity end-use consumption: Results from econometric and engineering models. Energy Econ. 2004, 26, 179-200.

8. Lutz, J.D.; Klein, G.; Springer, D.; Howard, B.D. Residential Hot Water Distribution Systems: Roundtable Session; Lawrence Berkeley National Laboratory: Berkeley, CA, USA, 2002.

9. Ndoye, B.; Sarr, M. Influence of domestic hot water parameters on the energy consumption of large buildings in Senegal. Energy Convers. Manag. 2003, 44, 2635-2649.

10. Bouchelle, M.; Parker, D.; Anello, M. Factors influencing water heating energy use and peak demand in a large scale residential monitoring study. In Proceedings of the Twelfth Symposium on Improving Building Systems in Hot and Humid Climates, San Antonio, TX, USA, 15-17 May 2000.

11. Aydinalp, M.; Ismet Ugursal, V.; Fung, A.S. Modeling of the space and domestic hot-water heating energy-consumption in the residential sector using neural networks. Appl. Energy 2004, 79, 159-178.

12. Yao, R.; Steemers, K. A method of formulating energy load profile for domestic buildings in the UK. Energy Build. 2005, 37, 663-671. 
13. Instituto Manual de fundamentos técnicos de calificación energética de edificios existentes $\mathrm{CE}^{3} \mathrm{X}$. 2012. Available online: http://www.minetur.gob.es/energia/desarrollo/EficienciaEnergetica/ CertificacionEnergetica/DocumentosReconocidos/Documents/Manual_fundamentos_tecnicos_CE3X_ 05.pdf (accessed on 11 September 2014). (In Spanish)

14. Thermal Solar Systems for Domestic Hot Water Production. Calculation Method for Heat Demand; UNE 94002:2005; Asociación Española de Normalización y Certificación (AENOR): Madrid, Spain, 2005.

15. León, A.L.; Muñoz, S.; León, J.; Bustamante, P. Monitorización de variables medioambientales y energéticas en la construcción de viviendas protegidas: Edificio cros-pirotecnia en sevilla. Inf. Constr. 2010, 62, 67-82. (In Spanish)

16. Jones, D.T.L. The Principal Types of Mixer-Valve Showers and Reducing Risks Associated with Legionella Bacteria. Available online: http://www.safepurge.co.uk/library/safepurgewmspaper.pdf (accessed on 11 September 2014).

17. Stone, M.; Ahmed, J.; Evans, J. The continuing risk of domestic hot water scalds to the elderly. Burns 2000, 26, 347-350.

18. Código Técnico de la Edificación (CTE-HE4). Available online: http://www.terra.org/ data/cteseccionhe4.pdf (accessed on 11 September 2014). (In Spanish)

19. Regulation of Thermal Behaviour Characteristics in Buildings; Decree Law 80:2006; Energy Performance of Buildings Directive (EPBD): Coimbra, Portugal, 2006.

20. Design, Installation, Testing and Maintenance of Service Supplying Water for Domestic Use Within Buildings and Their Curtilages Specification; British Standard BS6700; British Standards Institution (BSI): London, UK, 2006.

21. Encuesta sobre el Suministro y Saneamiento del Agua. Available online: http://www.ine.es/prensa/ np807.pdf (accessed on 11 September 2014). (In Spanish)

22. Encuesta Sobre Consumo Energético. Available online: http://www.cc.uah.es/consumo/ (accessed on 11 September 2014). (In Spanish)

23. Sauri, D. Lights and shadows of urban water demand management: The case of the metropolitan region of Barcelona. Eur. Plan. Stud. 2003, 11, 229-243.

24. Manuel Rico-Amoros, A. Tipologías de consumo de agua en abastecimientos urbano-turísticos de la Comunidad Valenciana. Investig. Geogr. 2007, 42, 5-34. (In Spanish)

25. Gascon, L.; Arregui, F.; Cobacho, R.; Cabrera, E. Urban water demand in Spanish cities by measuring end uses consumption patterns. In Proceedings of the Water Sources Conference, Austin, TX, USA, 11-14 January 2004.

26. Jensen, S. Saving Potential of Energy Labelled Taps and Showers; SP Report 2014:3P08445; SP Technical Research Institute of Sweden: Borås, Sweden, 2014.

27. Parker, D.S. Research highlights from a large scale residential monitoring study in a hot climate. Energy Build. 2003, 35, 863-876.

28. Papakostas, K.T.; Papageorgiou, N.E.; Sotiropoulos, B.A. Residential hot water use patterns in Greece. Sol. Energy 1995, 54, 369-374.

29. Measurement of Domestic Hot Water Consumption in Dwellings. Available online: https://www.gov.uk/government/uploads/system/uploads/attachment_data/file/48188/3147-measuredomestic-hot-water-consump.pdf (accessed on 11 September 2014). 
30. Burzynski R.; Crane, M.; Yao, R. A review of domestic hot water demand calculation methodologies and their suitability for estimation of the demand for zero carbon houses. In Proceedings of Conference: TSBE EngD Conference, University of Reading, Reading, UK, 6 July 2010.

31. Guía técnica. Agua caliente sanitaria central. 2010. Available online: http://www.minetur. gob.es/energia/desarrollo/eficienciaenergetica/rite/reconocidos/reconocidos/acs.pdf (accessed on 11 September 2014). (In Spanish)

32. Salmeron, J.M.; Cerezuela, A.; Salmeron, R. Escala de calificación. Edificios existentes. Available online: http://www.idae.es/uploads/documentos/documentos_11261_EscalaCalifEnerg_ EdifExistentes_2011_accesible_c762988d.pdf (accessed on 11 September 2014). (In Spanish)

33. Salmeron, J.M.; Cerezuela, A.; Salmeron, R. Escala de Calificación Energética. Edificios de Nueva Construcción. Available online: http://www.minetur.gob.es/energia/desarrollo/eficienciaenergetica/ certificacionenergetica/documentosreconocidos/otrosdocumentos/calificaci\%C3\%B3n\%20energ\% C3\%A9tica.\%20viviendas/escala_\%20calif_energetica.pdf (accessed on 11 September 2014). (In Spanish)

34. Izquierdo, M.; Moreno-Rodriguez, A.; Gonzalez-Gil, A.; Garcia-Hernando, N. Air conditioning in the region of Madrid, Spain: An approach to electricity consumption, economics and $\mathrm{CO}_{2}$ emissions. Energy 2011, 36, 1630-1639.

35. Survey on Households and the Environment 2008. Available online: http://www.ine.es/jaxi/menu.do? type=pcaxis\&path=/t25/p500/2008/p01/\&file=pcaxis (accessed on 11 September 2014).

36. Instituto Nacional de Estadística (INE). Available online: http://www.ine.es/ (accessed on 11 September 2014).

37. Water Heater Guide. Natural Resources Canada. 2012. Available online: http://publications.gc.ca/ collections/collection_2013/rncan-nrcan/M144-243-2012-eng.pdf (accessed on 11 September 2014).

38. Randolph, B.; Troy, P. Attitudes to conservation and water consumption. Environ. Sci. Policy 2008, 11, 441-455.

39. Scoping Study to Investigate Measures for Improving the Water Efficiency of Buildings; GHD Pty. Ltd.: Canberra, Australia, 2006.

40. Laitala, K.; Vereide, K. Washing Machines' Program Selections and Energy Use; National Institute for Consumer Research: Oslo, Norway, 2010.

41. Laitala, K.; Boks, C.; Klepp I.G. Potential for environmental improvements in laundering. Int. J. Consum. Stud. 2011, 35, 254-264.

42. Pakula, C.; Stamminger, R. Electricity and water consumption for laundry washing by washing machine worldwide. Energy Effic. 2010, 3, 365-382.

43. Wahlstrom, A. Water and Energy Saving by Installation of New Water Taps; SP Energy Technology: Vårgårda, Sweden, 2000.

44. Bernando, L.R.; Davidsson, H. Karlsson, B. Retrofitting domestic hot water heating systems in single-family houses in a cold climate: A theoretical analysis. Energies 2012, 5, 4110-4131.

(C) 2014 by the authors; licensee MDPI, Basel, Switzerland. This article is an open access article distributed under the terms and conditions of the Creative Commons Attribution license (http://creativecommons.org/licenses/by/4.0/). 